parent shell, moving in the snail's liver. So great is the injury done, that in the laboratory, at any rate, very few snails survive three weeks from infection.

The redia increases in size, and may ultimately reach the length of $I^{\prime} 3 \mathrm{~mm}$. or about one-twentieth of an inch. It resembles in every respect the redia I formerly described as found in the same snail at Wytham. Its contents of spherical cells arranged themselves into round germs as in the sporocyst, though I was able in this case to observe the formation of a gastrula. The germs at first were spherical, they then become oval, and afterwards they elongate still more, whilst one end becomes narrower than the other. The narrower end is partially constricted from the remainder, and, becoming long and slender, forms the tail of the cercaria, whilst the rest of the germ becomes the body. A sucker appears at the anterior end, and another of nearly equal size at the middle of the ventral surface of the flattened body, whilst within a digestive tract appears. This digestive tract is simply forked, and presents no trace of the lateral branches so characteristic of the adult.

The adult redia contains about a score of germs, but these are in very different stages of development. There are generally two or three nearly mature, the others in various stages down to small spheres of cells. Close to the raised ring surrounding the body of the cercaria there is a small opening as in all redix, by means of which the cercariae are destined to be liberated one by one as they come to maturity.

But not all the rediae produce cer cariae, for they sometimes produce other rediae, and these daughter-rediae then give rise to cercariae. These latter, therefore, sometimes only appear as the fourth generation in the snail, and in one set of experiments I had reason to believe that no cercariae appeared earlier. It will thus be seen that a single embryo may give rise to more than a thousand cercariae.

In April of the Ipresent year Leuckart published a paper in the "Archiv für Naturgescbichte," where he described certain experiments on the development of the liver-fluke. He believed that Limnaeus pereger was the intermediate host, and had succeeded in infecting this species, though he had failed to rear the redia beyond the stage in which the contents were forming into spores. He had, however, obtained a number of $L$. truncatulus from a friend, and had found in them three different sorts of rediae. One of these contained tail-less distome larvae, and not withstanding that the characters of the redia were very different from those reared from the embryo of the liverfluke, he believed the conjecture that this was really the larva of the liver-fluke to be entirely justified until further results were obtained. The second form he considered migbt possibly be related to the liver-fluke, but the probability was far less than in the case of the tailless form. In his description of the third form I at once recognised the cercaria I had already found and suggested as the larva of the liver-fluke. Leuckart, however, did not consider that there could be any connection, because he failed to detect any spines on the surface of the body such as we should expect, and on account of the lobed lateral organs, which he thought might be the vitellaria of the adult.

I wrote a report of my own results as described above, giving them, however, in greater detail, for the October number of the Journal of the Royal Agricultural Society. This report was sent to the printer on the Ist of September, and a fortnight later received a revision which was merely verbal.

On October 9 th a paper by Leuckart appeared in the Zoologischer Anzeiger, a periodical which gives rapid publication to important papers. In this Leuckart extends his former results, and states that he too has reared the cercaria of the liver-fluke in L. truncatulus, and finds that it is the form with the lobed lateral organs which he had already seen, and supposed to have no connection with the liver-fluke. It will be seen, therefore, that the cercaria of the liver-fluke is really the form found by me in Limnaeus truncatulus at Wytham, and described in the Royal Agricultural Society's Journal for 188I. It is interesting to see this result confirmed, not only by my own experiments, but also by Leuckart's independent investigations.

Leuckart has not been able to find any trace in the cercaria of the spines which cover the surface of the adult fluke. He has, however, found in the cells of the cercaria small rod shaped bodies closely resembling bacteria in shape and size, and thinks they may eventually be arranged in bundles and form the spines of the adult. But I have already stated that the anterior part of the body of the cercaria is covered with exceedingly fine spines, which can, however, only be seen in the most mature examples. The reason why Prof. Leuckart could not observe these spines was possibly because. his examples were scarcely so mature. The rod-like bodies he mentions have certainly no connection with the spines of the adult. He states that they have never yet been found in other cercariae. I may perhaps be allowed to say that they have been described by three different observers, first by Wagener, then by Filippi in the cercaria of Amphistoma subclavatum, and by myself in the cercaria of the liver-fluke (described in April, I88r.

For further details of the structure and natural history of the liver-fluke, as well as the discussion of preventive measures, I may refer to my reports in the Journal of the Royal Agricultural Society.

University Museum, Cxford, October I 3

A. P. THOMAS

\section{A NEW CASE OF COMMENSALISM}

CASES of Commensalism amongst the higher animals are rare. Those of the Prairie dog and Rattlesnake, in North America, and of the Burrowing $\mathrm{Owl}$ and Vizcacha in the Pampas of Buenos Ayres, are, however, familiar instances of it. The newly issued volume of the "Transactions and Proceedings of the New Zealand Institute" contains a communication from Prof. von Haast on a new and interesting case of two very different animals owning a common habitation.

One of these creatures being exceedingly scarce and little known, a few details upon this curious subject will be the more acceptable.

In December I880, Mr. Reis shek (a correspondent of Prof. v. Haast) paid a visit to a cluster of islands, called the "Chickens" situated East of Wangarei Bay on the East coast of the North Island of New Zealand. These Islands are now uninhabited by man but contain numerous remains of Maori Pahs and Kitchen-Middens showing that they were formerly much resorted to by the Natives.

The present inhabitants consist of certain species of birds, of which Mr. Reischek furnishes a list, and of multitudes of the celebrated Tuxtara Lizard (Sphenodon bunctatus)-one of the most anomalous forms of the Lacertian order, if, indeed, we are permitted by Dr. Günther to call it a Lizard at all.

Of these birds certain Petrels (namely Procellaria gouldi, $P$. Cooki, and Puffinus gavnus) live in holes dug out by the Tuataras and keep apparantly on the best terms with them. The Tuatara, we are told, excavates its hole mostly on the western slopes of the Islands. The entrance to its chamber is generally four or five inches in diameter, and the passage leading to it often two or three feet long, first descending and then ascending again. The chamber itself is about one foot and a half long, by one foot wide and six inches high and is lined with grass and leaves. The Petrels and Tuataras have their nests separately, one on each side of the entrance, so that they in no way interfere with one another. 
Generally the Tuatara lives on the right side and the Petrel on the left. Mr. Reischek says he sometimes found two Petrels inhabiting their side of the chamber but never two Tuataras together.

$\mathrm{He}$ is certain that the Tuataras in most cases excavate the holes as he watched them doing it, and moreover found them in holes only half finished without any birds with them. But there is no doubt that in some instances the Tuataras also inhabit holes dug out by the Petrels. $\mathrm{Mr}$. Reischek likewise gives us some interesting facts about the 'Tuataras' habits.

During the daytime these lizards are seldom met with outside their holes, and never far from the entrances. But as soon as the sun has set, the Tuatara leaves its hole to seek its foad, which consists of worms, beetles, etc. It also feeds on the remnants of fishes and crustaceans brought by the Petrel into the chamber. During the night, a peculiar croaking sound is heard emanating from

\section{THE CUMET}

I SEND a few sketches and a brief account of the comet Cruls. I found the comet at IIh. a.m. September 22 , by sweeping the sky near the sun with the ro-inch refractor of the Observatory of Palermo. It was nut an easy object to find; it seems but a point with a these lizards, not unlike the grunting of a pig when it is tormented. This is the best time to catch the Tuataras. Mr. Reischek believes that the female Sphenodon lays its eggs in February, as in January he found in one of them eight fully developed eggs, and about the same time obtained a young one only eight inches long including the tail.

So little has been hitherto recorded concerning the habits of the Tuatara in a state of Nature that these facts ascertained by Mr. Reischek and communicated by Professor von Haast to the New Zealand Institute must be allowed to be of great interest. Although the Tuatara has not unfrequently been brought alive to this country, and there are at the present time two examples of it living in the Zoological Society's Collection, this reptile is already quite extinct upon the main-land of New Zealand and exists only in some of the more remote islets which border its northern shores.

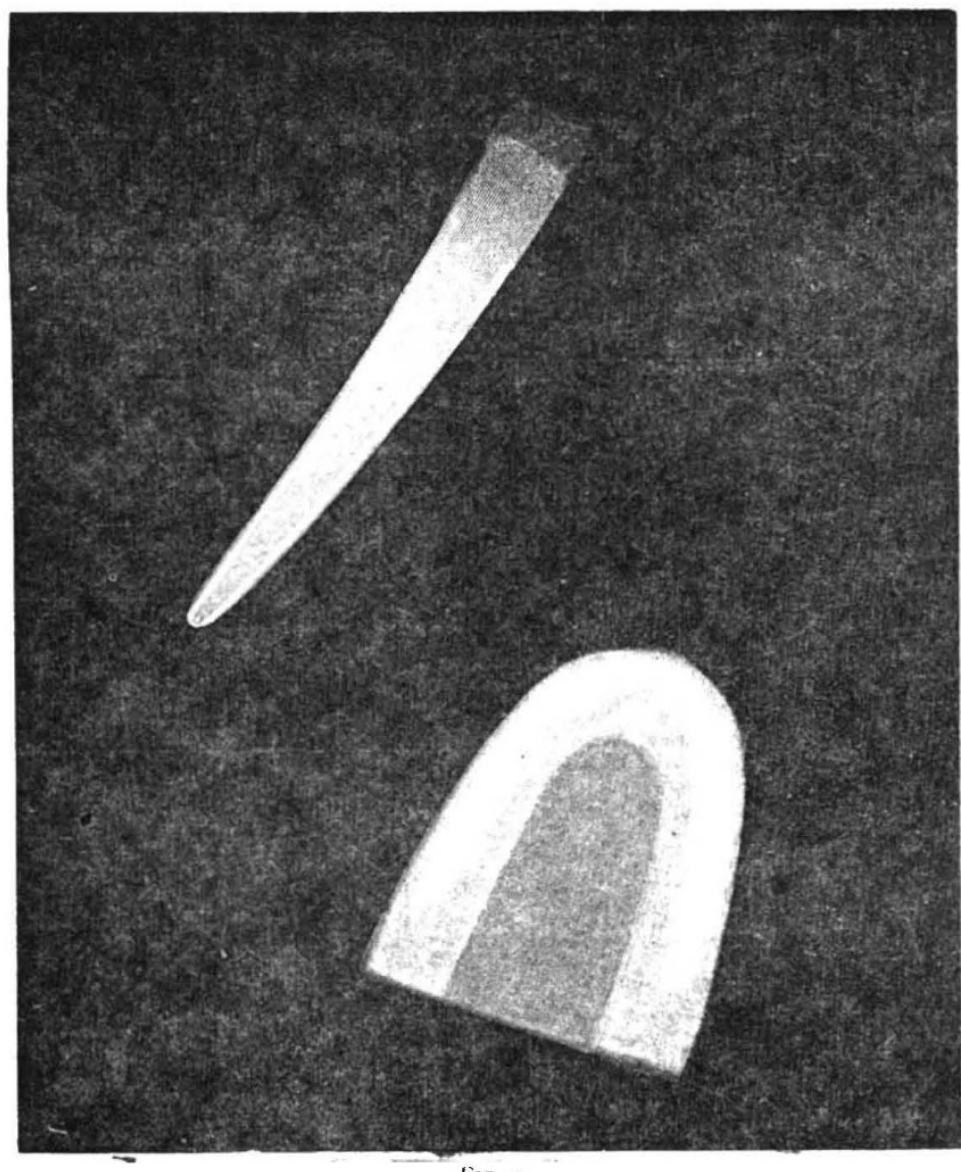

surrounding nebulosity, and a trace of tail directed to the south-west.

On the following morning the comet had the form (observed by Prof. Zona and myself) of Fig. I, and preserved it until September 27 ; the tail was very splendid, inclined $50^{\circ}$ to the horizon (that is to say, nearly parallel to the equator), a little convex to the south; the visible

Fig. I.

langth in the glare of dawn and moo was $6^{\circ}$, and then spectrum of the nucleus, traversed by a large and strong $10^{\circ}$; the breadth at the top was $40^{\prime}$, and then $I^{\circ} I^{\prime}$. line, that of sodium (D); by enlarging the slit of the The nucleus was round and very brilliant, with a spectroscope, I saw a globular, monochromatic image of yellowish light.

The spectrum was formed of the linear continuous the nucleus and coma. Besides the line of sodium, many others were present, but my spectroscope not having a 